\title{
Adversity quotient of students during covid-19 outbreak
}

\author{
Asni Asni ${ }^{{ }^{*}}$, Siti Salsa Nabilah ${ }^{1}$, Nurul Fajri ${ }^{1}$, Dini Chairunnisa ${ }^{1}$ \\ ${ }^{1}$ Universitas Muhammadiyah Prof. Dr. Hamka, Indonesia
}

\begin{tabular}{l}
\hline Article Info \\
\hline Article history: \\
Received Mar $04^{\text {th }}, 2021$ \\
Revised Apr $16^{\text {th }}, 2021$ \\
Accepted May $21^{\text {st }}, 2021$ \\
\hline
\end{tabular}

\section{Keyword:}

Adversity quotient

Student

Covid-19 outbreak

\begin{abstract}
Adversity quotient is one of the intelligences possessed by a person in managing difficulties into a challenge that must be resolved to achieve certain goals. So that the adversity quotient must be owned by students to face various difficulties in completing lectures. However, during the Covid-19 pandemic, student activity became limited, both in following the learning process and guidance in completing final assignments in the form of a thesis, which was increasingly difficult. The purpose of this study was to determine the level of adversity quotient of students during the Covid-19 pandemic. This research method is descriptive quantitative. The sample in this study numbered 237 students and were selected using proportional random sampling technique. This study uses an adversity quotient scale with a reliability level of 0.924 in the very good category. The data analysis technique used the score range/categorization formula. The results showed $7.2 \%$ or 17 guidance and counseling students had low adversity quotient, $67.1 \%$ or 159 students had medium adversity quotient and $25.7 \%$ or 61 students had high adversity quotient. It can be concluded that students in general tend to have a moderate adversity quotient during the Covid-19 epidemic. These findings indicate it is necessary to conduct a college level counseling and guidance program to increase the adversity quotient of students.
\end{abstract}

(C) 2021 The Authors. Published by IICET.

This is an open access article under the CC BY-NC-SA license

(https://creativecommons.org/licenses/by-nc-sa/4.0)

\section{Corresponding Author:}

Asni Asni,

Universitas Muhammadiyah Prof. Dr. Hamka

Email: asni@uhamka.ac.id

\section{Introduction}

The Covid-19 pandemic is an event that the spread of the 2019 coronavirus disease around the world (Andersen et al., 2020) has disrupted human health and even resulted in high mortality in a very short period of time (Saputra \& Putra, 2020). Based on information from merdeka.com the coronavirus pandemic in Indonesia begins with findings from March 2020 to November that confirmed positive cases of Covid-19 were 538,883 cases. 450,518 patients recovered. The patient died 16,945 people. So in response to the pandemic the government began to impose large-scale social restrictions (PSBB) on several areas (Kemenkes, 2020; Nahar et al., 2020; Tobroni, 2020). The spread of the Covid-19 pandemic is increasingly widespread and is starting to have an impact on a number of aspects of life (Engkus et al., 2020), one of which is education (Tursina, 2020). The Minister of Education and Culture (Kemendikbud) issued Circular Letter Number 4 of 2020 (Kemendikbud, 2020) regarding the Implementation of Education Policies in an Emergency for the Spread of Coronavirus Disease (Covid-19) which includes directions on the learning process. from home (learning from home) (Yunus \& Rezki, 2020). This policy targets all levels of education from preschool to tertiary education, both public and private, implementing learning from home (LFH) (Arifa, 2020). 
The Minister of Education and Culture (Kemendikbud) issued Circular Letter Number 4 of 2020 regarding the Implementation of Education Policies in an Emergency for the Spread of Coronavirus Disease (Covid-19) which includes directions on the learning process from home (learning from home) (Yunus \& Rezki, 2020). This policy targets all levels of education from preschool to tertiary education, both public and private, implementing learning from home (LFH) (Arifa, 2020). The Minister of Education and Culture (Kemendikbud) issued Circular Letter Number 4 of 2020 (Education, M., \& Indonesia, KR, 2020) regarding the Implementation of Education Policies in an Emergency for the Spread of Coronavirus Disease (Covid-19) which includes directions on the learning process. from home (learning from home) (Yunus \& Rezki, 2020). This policy targets all levels of education from preschool to tertiary education, both public and private, implementing learning from home (LFH). (Arifa, 2020) regarding the Implementation of Education Policies in an Emergency Period for the Spread of Coronavirus Disease (Covid-19), which includes directions on the learning process from home (Yunus \& Rezki, 2020). This policy targets all levels of education from preschool to tertiary education, both public and private, implementing learning from home (LFH) (사ifa, 2020), regarding the Implementation of Education Policies in an Emergency Period for the Spread of Coronavirus Disease (Covid-19), which includes directions on the learning process from home (Yunus \& Rezki, 2020). This policy targets all levels of education from preschool to tertiary education, both public and private, implementing learning from home (LFH) (Arifa, 2020).

Learning from home (LFH) is a learning activity from home that is carried out by e-lerning or online by utilizing a number of applications or social media such as WhatsApp, Google Classrom, Zoom and other media. The application of LFH is still active (Nalle et al., 2020), where learning is initially face-to-face in class (Speck, 1996) then switches to online (online) (Atsani, 2020). The learning system changes rapidly and suddenly, of course there is no proper preparation (Sumantyo, 2020; Yoanita, 2020). So that it creates its own difficulties both on the part of educators and students (Mishra et al., 2020; Radu et al., 2020). The difficulties experienced are limited internet connection (Yelinska, 2020), limited ability to operate the internet (Handani et al., 2020). Limited time to do assignments (Setiawan, 2020), the learning process is still rigid (Herliandry et al., 2020) and not all students have devices to learn online (Astini, 2020) and cannot understand the material with good (EdSource, 2020). Some of the difficulties experienced by students in the learning process must be handled immediately, because they will have fatal effects such as increasing academic anxiety (Suranata \& Prakoso, 2020), lower learning motivation (Cahyani et al., 2020), learning achievement has decreased (Zulhafizh, 2020).

The Covid-19 pandemic has had a significant impact both mentally and physically on everyone. Individuals experience a period where they must adapt to all policies from the covid-19 pandemic. During the Covid-19 pandemic, an individual adversity quotient is needed to face challenges during a pandemic. Individuals who have a good adversity quotient can withstand constant adversity and change (Hartosujono, 2015). This is very important for students to do, especially in overcoming difficulties in learning from home (LFH). As found in research, during the Covid-19 pandemic, students had high stress (Choompunuch et al., 2021). Stress can affect individual behavior (Pellegrini et al., 2021) so that it can reduce productivity, for example, in students, a lack of motivation to attend lectures, delays in doing lecture assignments and being paranoid about university life (Choompunuch et al., 2021).

Individual adversity quotient needs to be increased because the higher the adversity of the individual, the higher the individual's health behavior (Suksatan et al., 2021). Individuals who have a good adversity quotient can face and survive the hard conditions / events they face (Hulaikah \& Degeng, 2020). A good adversity quotient can help students who are working on their thesis. So that it needs to be improved among students to help students in working on their thesis, especially during the pandemic.

One alternative to alleviate various LFH learning problems during the Covid-19 pandemic is the need to equip oneself with high strength and resilience (Napis, 2018) in order to be able to participate in the learning process optimally (Hasanah, 2010) and be able to completed the study well (Suhartono, 2017) in difficulties with limited learning spaces during the pandemic (Atsani, 2020). This strength and resistance is usually called the Adversity Quotiet (Yakoh et al., 2015). Adversity Quotientis a person's ability to respond to difficulties to be able to survive and then overcome them. and will turn it into an opportunity for success and success so as to produce change for the better (Stoltz, 2000). By having a good adversity quotient, increase the sense of responsibility in alleviating problems (Verma et al., 2017), increasing self-confidence in overcoming various difficulties, increasing achievement motivation higher (Fahmi \& Rachmahana, 2008). Students are one of the subjects in tertiary education, the demands of learning and study completion are higher than other levels of education (Asmawi, 2010), students are also mature and mature individuals in thinking, because these two things are factors that affect adversity. Individual quotient (Ratnawulan, 2020), so expectation level Adversity 
Quotient students during the Covid-19 epidemic must be high. This study describes the level of Adversity Quotient during the Covid-19 pandemic.

\section{Method}

The method used in this research is quantitative research methods with a descriptive approach. This research was conducted at the University of Muhammadiyah Prof. Dr. Hamka, Faculty of Teacher Training and Education, East Jakarta. The population in this study were students of Guidance and Counseling in batch 2016, 2017, 2018 and 2019 totaling 584 students. The formula used to determine the sample size is the Slovin formula, so the total sample size is 237 students. Furthermore, the sampling technique is Proportional Random Sampling. Data collection uses a questionnaire regarding the level of adeversity quotient based on the theory of (Stoltz, 2000) which states that a person's adversity quotient can be measured in 5 dimensions, namely: Control, Origin and Ownership, Reach, and Endurance. The stages in compiling the questionnaire consist of; (1) understand some literacy regarding adversity quotient; (2) then the preparation of the questionnaire blueprint based on the predetermined literature, namely the dimension of adversity quotient according to Stoltz, which is done by describing the variables down to the statement items. Then proceed with testing the validity of the statement items and the reliability test of the questionnaire obtained by, 924 with very good category.

The research data were obtained from administering questionnaires to students. The stages of administering the data obtained from the questionnaire that have been compiled are as follows: (1) Preparing the research questionnaire after going through the feasibility study, namely the Vaid and Reliability test. (2) Determine the data source for distributing questionnaires via google form, then prepare the necessary supporting documents in the form of a research permit and so on. (3) Carry out systematic data collection in accordance with what has been previously planned. After the data has been collected, the final step is to tabulate and analyze the data, namely descriptive analysis to describe each sub variable and also the research indicators and determine the categorization through the interval range with the assistance of SPSS version 20.0 .

\section{Results and Discussions}

Descriptive level data analysis adversity quotient students numbered 237 respondents as follows:

Table 1. Frequency distribution and percentage of adversity quotient students during the Covid-19 Pandemic

\begin{tabular}{|c|c|c|c|}
\hline Category & Score Interval & $\mathbf{F}$ & $\%$ \\
\hline Low & $<121$ & 17 & 7.2 \\
\hline Moderate & $122-158$ & 159 & 67.1 \\
\hline High & $>159$ & 61 & 25.7 \\
\hline \multicolumn{2}{|c|}{ Total } & 237 & 100 \\
\hline
\end{tabular}

In table 1 , it is known that the level during the Covid-19 pandemic was in the low category of $7.2 \%$, the moderate category was $67.1 \%$ and the high category was $25.7 \%$. This means that the adversity quotient of Uhamka's guidance and counseling students still needs to be improved.

Table 2. Student adversity quotient based on sub variable

\begin{tabular}{lcccccccc}
\hline Sub Variabel & Ideal & Min & Max & Sum & Mean & Mean\% & SD & Ket \\
\hline Control & 32 & 15 & 32 & 5611 & 23,68 & 74 & 3,629 & S \\
\hline Origin dan Ownership & 88 & 46 & 87 & 15834 & 66,81 & 76 & 8,265 & S \\
\hline Reach & 40 & 17 & 40 & 7263 & 30,65 & 77 & 4,611 & S \\
\hline Endurance & 36 & 14 & 36 & 5968 & 25,18 & 70 & 4,912 & S \\
\hline Total & 196 & 92 & 195 & 34676 & 146,32 & 75 & 21,417 & $\mathrm{~S}$ \\
\hline
\end{tabular}


Based on table 2, it is known that the percentage of adversity quotient based on the above sub-variables; it is known that the adversity quotient of guidance and counseling students is dominant in the moderate category. As for the sub variable, the highest percentage is the reach sub variable (ability to face adversity) and the lowest percentage is the endurance sub variable (self-resistance in perceiving adversity). This means that the adversity quotient of UHAMKA's guidance and counseling students on the aspect of ability to deal with adversity has been fulfilled but still needs to be improved and the aspect of self-resilience in perceiving adversity needs to be improved.

After conducting research on guidance and counseling of UHAMKA students in batch 2016-2019 with a total of 237 respondents / sample, the results showed that guidance and counseling of UHAMKA students tend to have a moderate adversity quotient level. This is shown by the percentage results that reached $67.1 \%$ or as many as 159 students got the moderate category. Meanwhile, in the low category, there were $7.2 \%$ or 17 students. And for the high category there were $25.7 \%$ or as many as 61 students.

The results of this study indicate that students who are in the low category tend to give up easily and give up hope, especially in facing challenges during the Covid-19 pandemic, one of which is when implementing learning from home (LFH). According to (Stoltz, 2000) people in the low category are referred to as Quitters, namely people who opt out, avoid obligations, resign, and quit. Individuals with this type choose to stop trying, they ignore, cover up and leave behind the core human urge to keep trying. Thus, individuals with this type usually leave many things that life has to offer, the name of which is found in students by $7.2 \%$.

Meanwhile, students who are in the medium category have a tendency to be able to survive the existing problems or challenges they get. But they will choose to try slowly or even stop. People who have a moderate adversity quotient are said to be between the threshold, which will either face what they want or endure as needed. According to (Stoltz, 2000), the category being referred to as Campers or people who camp are people who have tried a little and are easily satisfied with what they have achieved. This type is usually bored in climbing and then finds a comfortable position and hides in friendly situations. Most of the campers consider their life to be successful, so there is no need for repairs and efforts anymore.

And the high category is students who have good survival skills. They are able to face the challenges and problems they face, especially when learning from home during the Covid-19 pandemic becomes a fun opportunity or challenge for them. According to (Stoltz, 2000) this high category is referred to as Climbers or the climber is an individual who makes efforts throughout his life. Regardless of background, gain or loss, good or bad luck, this type of individual will continue to try. This was obtained by students, namely $25.7 \%$. There are several factors that affect the level of adversity quotation of high students, namely the motivation of students to continue graduating on time (Fahmi \& Rachmahana, 2008). There are several things that can be done to improve the Adversity Quotient of students, namely by providing group guidance services in collaboration with UPBK (Counseling Guidance Service Unit) in their respective universities. Furthermore, it can also be done with outbone activities (Rachmadinna, 2018) as well as various approaches in counseling such as focus group discussions (Nurvita, 2019). Based on the explanation above, in order to increase the adversity quotient of students through guidance and counseling services at the university level.

\section{Conclusions}

This indicates that students are quite capable or are categorized as being in the dimensions of adversity quotient such as sufficient in controlling themselves, being in knowing the origin of the problem and not making themselves as one of the causes of problems, sufficient in managing the range of problems so that they do not spread to other aspects of life and has moderate fighting power.

\section{References}

Andersen, K. G., Rambaut, A., Lipkin, W. I., Holmes, E. C., \& Garry, R. F. (2020). The proximal origin of SARS-CoV-2. Nature medicine, 26(4), 450-452.

Arifa, F. (2020). Tantangan Pelaksanaan Kebijakan Belajar Dari Rumah Dalam Masa Darurat Covid-19. Info Singkat; Kajian Singkat Terhadap Isu Aktual Dan Strategis, XII (7/I), 6. Jurnal Bidang Kesejahteraan Sosial, 12.

Asmawi, M. R. (2010). Strategi meningkatkan lulusan bermutu di perguruan tinggi. Hubs-Asia, 10(1).

Astini, N. K. S. (2020). Pemanfaatan teknologi informasi dalam pembelajaran tingkat sekolah dasar pada masa pandemi covid-19. Lampuhyang, 11(2), 13-25.

Atsani, K. L. G. M. Z. (2020). Transformasi media pembelajaran pada masa Pandemi COVID-19. Al-Hikmah: Jurnal Studi Islam, 1(1), 82-93. 
Cahyani, A., Listiana, I. D., \& Larasati, S. P. D. (2020). Motivasi Belajar Siswa SMA pada Pembelajaran Daring di Masa Pandemi Covid-19. IQ (Ilmu Al-qur'an): Jurnal Pendidikan Islam, 3(01), 123-140.

Choompunuch, B., Suksatan, W., Sonsroem, J., Kutawan, S., \& In-udom, A. (2021). Stress, adversity quotient, and health behaviors of undergraduate students in a Thai university during COVID-19 outbreak. Belitung Nursing Journal, 7(1), 1-7.

EdSource. (2020). Coronavirus: Highlighting strategies for student success. https://edsource.org/topic/coronavir

Engkus, E., Suparman, N., Tri Sakti, F., \& Saeful Anwar, H. (2020). Covid-19: Kebijakan mitigasi penyebaran dan dampak sosial ekonomi di Indonesia. LP2M.

Fahmi, S., \& Rachmahana, R. S. a. (2008). Adversity Quotient (AQ) dan Motivasi Berprestasi Pada Siswa Program Akselerasi dan Program Reguler. Gifted Review. Jurnal Keterbakatan dan Kreativitas, 2(2), 103-115.

Handani, S. W., Magnolia, C., \& Pratama, R. A. (2020). Pelatihan Penggunaan Virtual Class Sebagai Media Pembelajaran Bagi Guru dan Siswa SMK Negeri 1 Banyumas Pada Masa Pandemi COVID-19. JPMM (Jurnal Pengabdian Mitra Masyarakat), 2(2), 141-149.

Hartosujono, H. (2015). Perilaku Adversity Quotient Mahasiswa Ditinjau dari Locus of Control. Sosiohumaniora : Jurnal Ilmiah Ilmu Sosial Dan Humaniora, 1(1), 64-73.

Hasanah, H. (2010). Hubungan antara adversity quotient dengan prestasi belajar siswa SMUN 102 Jakarta Timur [Skripsi, UIN Syarif Hidayatullah]. Jakarta.

Herliandry, L. D., Nurhasanah, N., Suban, M. E., \& Kuswanto, H. (2020). Pembelajaran pada masa pandemi covid-19. JTP-Jurnal Teknologi Pendidikan, 22(1), 65-70.

Hulaikah, M., \& Degeng, I. (2020). The Effect of Experiential Learning and Adversity Quotient on Problem Solving Ability. International Journal of Instruction, 13(1), 869-884.

Surat Edaran Nomor 4 Tahun 2020 tentang Pelaksanaan Kebijakan Pendidikan dalam Masa Darurat Penyebaran Coronavirus Disease (COVID-19), (2020).

Kemenkes. (2020). Pedoman Pemberdayaan Masyarakat dalam Pencegahan Covid-19 di RT/RW/Desa. Journal of Chemical Information and Modeling, 53(9), 1689-1699.

Mishra, L., Gupta, T., \& Shree, A. (2020). Online teaching-learning in higher education during lockdown period of COVID-19 pandemic. International Journal of Educational Research Open, 1, 100012.

Nahar, L., Rusi, M., \& Ujiantuti, E. (2020). Strategi Pemerintah Indonesia Dalam Membentuk Opini Publik Terkait Pemberlakuan PSBB. Jurnal Syntax Transformation, 1(9), 632-640.

Nalle, A. P., Saba, K. R., \& Masi, L. M. (2020). Gambaran Motivasi Belajar Mahasiswa BK FKIP Undana Mengikuti Pembelajaran Berbasis Daring Selama Masa Pandemic. Journal Of Physical Education Health And Sport Sciences, 1(2), 94-105.

Napis, N. (2018). Analysis of Physics Problem Solving in The Perspective of Self Efficacy and Adversity Quotient. Formatif: Jurnal Ilmiah Pendidikan MIPA, 8(1).

Nurvita, D. N. (2019). Peningkatan Adversity Quotient melalui Strategi Focus Group Discussion pada Mahasiswa. At-Taujih: Bimbingan dan Konseling Islam, 2(1), 54-72.

Pellegrini, C. A., Webster, J., Hahn, K. R., Leblond, T. L., \& Unick, J. L. (2021). Relationship between stress and weight management behaviors during the COVID-19 pandemic among those enrolled in an internet program. Obesity Science \& Practice, 7(1), 129-134.

Rachmadinna, A. M. (2018). Pengembangan paket bimbingan dengan teknik outbond untuk meningkatkan adversity quotient siswa SMP Universitas Negeri Malang]. Malang.

Radu, M.-C., Schnakovszky, C., Herghelegiu, E., Ciubotariu, V.-A., \& Cristea, I. (2020). The Impact of the COVID-19 Pandemic on the Quality of Educational Process: A Student Survey. International Journal of Environmental Research and Public Health, 17(21), 7770.

Ratnawulan, F. (2020). Perbedaan tingkat Adversity Quotient pada mahasiswa etnis Sunda, Jawa, dan Minangkabau UIN Sunan Gunung Djati Bandung].

Saputra, C., \& Putra, I. D. (2020). Pemberdayaan Penanggulangan Covid-19 Bagi Petugas Kesehatan. JCES (Journal of Character Education Society), 3(2), 311-319.

Setiawan, L. D. (2020). Permasalahan Pendidikan Indonesia di Tengah Pandemi Covid-19. Prosiding Seminar Nasional Bahasa dan Sastra Indonesia (SENASBASA),

Speck, M. (1996). The change process in a school learning community. School Community Journal, 6, 69-80.

Stoltz, P. G. (2000). Adversity quotient. Grasindo.

Suhartono, S. (2017). Adversity Quotient Mahasiswa Pemrogram Skripsi (Adversity Quotient of Student Programming Thesis). Matematika Dan Pembelajaran, 5(2), 209-220.

Suksatan, W., Choompunuch, B., Koontalay, A., Posai, V., \& Abusafia, A. H. (2021). Predictors of Health Behaviors Among Undergraduate Students During the COVID-19 Pandemic: A Cross-Sectional Predictive Study. Journal of multidisciplinary healthcare, 14, 727.

Sumantyo, F. D. S. (2020). Pendidikan Tinggi di Masa dan Pasca Covid-19. Jurnal Kajian Ilmiah, 1(1), 81-92. 
Suranata, K., \& Prakoso, B. B. (2020). Program web-based SFBC untuk mereduksi kecemasan akademik siswa saat pandemi COVID-19; sebuah pilot studi. JPPI (Jurnal Penelitian Pendidikan Indonesia), 6(2), 4752.

Tobroni, F. (2020). Pembatasan Kegiatan Keagamaan Dalam Penanganan Covid-19. Jurnal Komunikasi Hukum (JKH), 6(2), 369-395.

Tursina, A. (2020). COVID-19 dan lansia. In. Pusat Penerbitan Unisba (P2U) LPPM UNISBA.

Verma, S., Aggarwal, A., \& Bansal, H. (2017). The relationship between emotional intelligence (EQ) and adversity quotient (AQ). IOSR Journal of Business and Management, 19(1), 49-53.

Yakoh, M., Chongrukasa, D., \& Prinyapol, P. (2015). Parenting styles and adversity quotient of youth at Pattani foster home. Procedia-Social and Behavioral Sciences, 205, 282-286.

Yelinska, A. (2020). Some Issues on Organization of Educational Process in Higher Educational Institutions During Pandemic. Актуальні проблеми сучасної медицини: Вісник Украӥнської медичної стоматологічної академї, 20(3), 235-238.

Yoanita, D. (2020). Mendadak Daring (Refleksi Pembelajaran Jarak Jauh). Petra Press.

Yunus, N. R., \& Rezki, A. (2020). Kebijakan pemberlakuan lock down sebagai antisipasi penyebaran corona virus Covid-19. Salam: Jurnal Sosial dan Budaya Syar-i, 7(3), 227-238.

Zulhafizh, Z. (2020). Membina Aktivitas Belajar Mahasiswa di Perguruan Tinggi Melalui Metode TIE (Translation, Interpretation, Extrapolation) pada Masa Pandemi Covid-19. Jurnal Kependidikan: Jurnal Hasil Penelitian dan Kajian Kepustakaan di Bidang Pendidikan, Pengajaran dan Pembelajaran, 6(3), 502-511. 